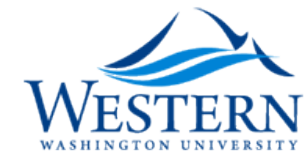

Western Washington University

Western CEDAR

$10-1996$

\title{
Timing of Latest Eocene Molluscan Extinction Patterns in Mississippi
}

David M. Hassl

Thor A. Hansen

Western Washington University, thor.hansen@wwu.edu

Follow this and additional works at: https://cedar.wwu.edu/geology_facpubs

Part of the Geology Commons

\section{Recommended Citation}

Hassl, David M. and Hansen, Thor A., "Timing of Latest Eocene Molluscan Extinction Patterns in Mississippi" (1996). Geology Faculty Publications. 6.

https://cedar.wwu.edu/geology_facpubs/6 


\section{Timing of Latest Eocene Molluscan Extinction Patterns in Mississippi}

\author{
DAVID M. HAASL* and \\ THOR A. HANSEN \\ Department of Geology, Western \\ Washington University, \\ Bellingham, WA 98225
}

PALAIOS, 1996, V. 11, p. 487-494

Molluscs removed from 12 bulk samples of the Yazoo Formation (upper Eocene), exposed in a quarry at Cynthia, Mississippi, are similar in composition and diversity to those found in the underlying upper Eocene Moodys Branch Formation, when differences in outcrop area are considered (74\% of the Yazoo species are also found in the Moodys Branch). This suggests there was no significant extinction during the late Eocene (at the P15/P16 biozone boundary) as has been reported for planktic foraminifera. Only $11.4 \%$ of the species from the Yazoo extend into the Oligocene Red Bluff Formation, suggesting a large molluscan extinction at or near the Eocene-Oligocene boundary. The presence in the lowermost Red Bluff of an assemblage with a relatively high diversity dominated by suspension-feeding bivalves suggests that the molluscan fauna had recovered from the extinction by the earliest Oligocene.

\section{INTRODUCTION}

The late Eocene marks the first major mass extinction after the close of the Cretaceous and is another mass extinction, besides the Cretaceous-Tertiary event, that has been definitely associated with evidence

\footnotetext{
* Current address: Dept. of Geology, University of California, Davis, CA 95616.
}

of bolide impacts. There is an iridium anomaly (Alvarez et al., 1982; Ganapathy, 1982) and at least three microtektite layers within the Upper Eocene (Byerly et al., 1988; Hazel, 1989). However, linking bolide impacts with the Eocene extinctions has thus far proved to be problematic and inconclusive (Corliss et al., 1984; Miller et al., 1991).

The extinction patterns of foraminifera and calcareous nannoplankton during the late Eocene have been widely studied and documented in the literature. Rather than an abrupt mass extinction at the end of the Eocene, microinvertebrates exhibited a stepwise extinction pattern that correlated with discrete episodes of global cooling (Keller, 1983; Snyder et al., 1984; Wei, 1991; Aubry, 1992; Thomas, 1992). These steps included a large decline in foraminiferal and nannoplankton species diversity at the middle/late Eocene boundary and a lesser decline during the late Eocene near the P15/P16 planktic foraminiferal zone boundary (Keller, 1986; Aubry, 1992; Fig. 1). The Eocene-Oligocene (E-O) boundary event among the planktic foraminifera has been characterized as an inconspicuous continuation of a decline at the Middle/Late Eocene boundary (Keller et al., 1992).

The late Eocene extinction patterns of benthic molluscs have been controversial. While most agree that molluscs suffered a major decline in gamma (landscape) diversity at the Middle/Late Eocene boundary (Dockery, 1986; Hansen, 1992), it has not been clear whether the molluscan diversity also declined during the late Eocene in step with the microfauna near the P15/P16 boundary (Hansen, 1987), or if it were characterized by a larger and more abrupt extinction at or near the E-O boundary
(Dockery, 1984; 1986). Fossil faunas in most of the Late Eocene deposits of the Gulf of Mexico are very poorly preserved and thus suffer from a preservational bias. However, an unusually well-preserved late Eocene outcrop at a quarry near Cynthia, Mississippi (Yazoo Formation, Figs. 1-2) contains a fine assemblage of deeper water molluscs that may help resolve this question. We report on a detailed collecting survey, taken mainly from bulk samples, of the Cynthia Pit locality for the purpose of resolving this controversy about the pattern of late Eocene molluscan extinctions.

\section{GEOLOGIC SETTING}

The late Eocene of Mississippi is represented by the Moodys Branch and Yazoo Formations which comprise the Jackson Group (Fig. 1). The Yazoo Formation is overlain by the Oligocene Red Bluff Formation of the Vicksburg Group. The JacksonVicksburg contact at the Chickasawhay River (MGS 35 and 38) is marked by a disconformity. However, Pasley and Hazel (1995) note that the amount of time missing at the boundary is below the limit of biostratigraphic resolution and is, therefore, unresolvable. The Moodys Branch represents the nearshore to middle shelf portions of a transgressive sequence and possesses an abundant, well preserved molluscan fauna in a sandy matrix (Elder and Hansen, 1981). The Yazoo, representing the latest Eocene, formed in a clay-rich, deep shelf environment and generally possesses sparse and poorly preserved molluscan fossils (Dockery and Siesser, 1984; Hansen, 1992). The Red Bluff Formation is a fossiliferous glauconitic, silty clay that represents a middle marine shelf environment (Dockery, 1982; MacNeil and Dockery, 1984; William Sliter, pers. comm., 1991).

The boundary between the Moodys Branch and Yazoo formations roughly coincides with the P15/P16 planktic foraminiferal zone boundary and the microfossil extinction accompanying it (Hansen, 1992). Therefore, even though these two 


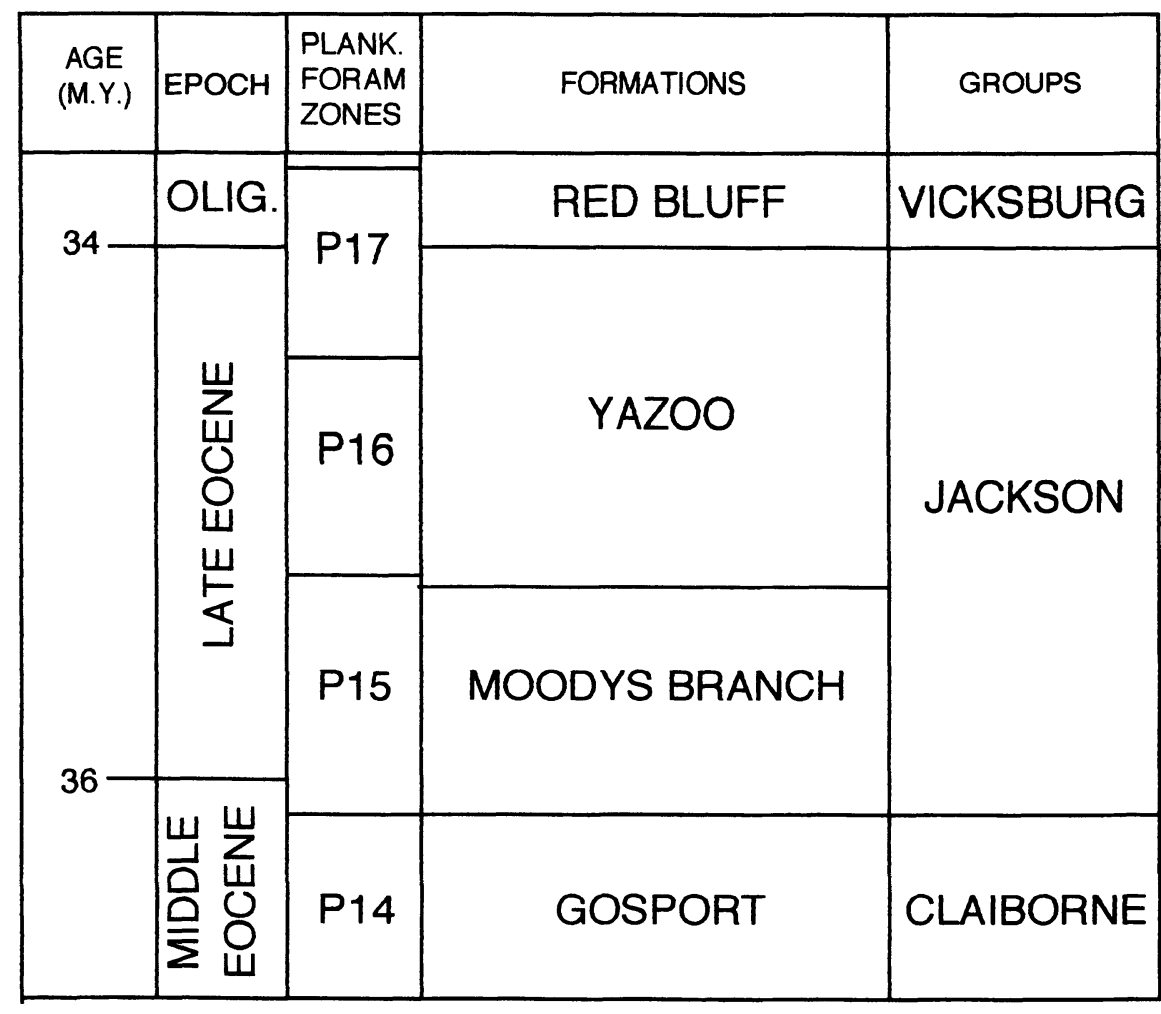

FIGURE 1-Correlation of studied formations with planktic foraminiferal biozones (taken from Hansen (1987).

formations represent very different facies, determining the number of Moodys Branch species that survived into the Yazoo is a critical first step in assessing the significance of the P15/P16 extinction event on molluses.

While the Yazoo is generally poorly fossiliferous, there are two fossilrich sections. One, the type Danville Landing locality near Catahoula Parish, Louisiana is no longer accessible for collecting due to inundation by the Ouachita River. The other section is exposed near Cynthia, Mississippi (see Fig. 2), in a quarry of the Miss Lite Division of the Jackson Ready-mix Concrete Company. The Yazoo Formation at the Cynthia Pit consists of 29 meters of fossiliferous, blocky, blue-gray clay. Fossils are present throughout the clay interspersed with shell-hash beds that become more closely spaced upsection. Smith and Zumwalt (1987) noted the preponderance of shallow-water microfossils in these shell-hash horizons in sharp contrast to the outer neritic fauna found elsewhere in the section. The shell-hash beds and the associated anomalous microfauna, were interpreted to be deposits of laminar gravity flows that carried shallow-water organisms to a quick burial in a deeper marine environment (Smith and Zumwalt, 1987).

Although Cynthia Pit does not cross the Eocene-Oligocene boundary, it is the next best thing. It lies between 15 and 45 meters from the top of the 135 meter thick Yazoo Formation (Dockery and Siesser, 1984), stratigraphically above most of the upper Eocene foraminiferal extinctions (Byerly et al., 1988). While direct chronologic dating of the section has not been attempted, a pair of bentonite beds assigned to a similar stratigraphic position (Obradovich et al., 1993) have been dated at approximately $34.3 \mathrm{Ma}$ using the ${ }^{40} \mathrm{Ar}-{ }^{39} \mathrm{Ar}$ radioisotope technique (Dockery et al., 1991). This date is consistent with Cynthia Pit's stratigraphic position in the upper third of the Yazoo and places the section within the fi- nal 600,000 years or so of the Eocene using the revised Paleogene timescale of Berggren et al. (1992).

\section{METHODS}

Twelve unweathered bulk samples (approx. $7 \mathrm{~kg}$ each) were collected at approximately $1.5 \mathrm{~m}$ intervals (Fig. 3). Samples were taken both within and between the shell-hash beds. The specimens in the hash beds were generally too broken to identify, so nearly all the identifiable specimens recovered from Cynthia Pit were from sediment outside of these event beds. Surface float was collected to obtain rare species. The bulk samples were dried and carefully washed through sieves with 1.00 and $0.25 \mathrm{~mm}$ openings. The specimens retained on the $1.00 \mathrm{~mm}$ sieve were removed and identified from the literature (Harris and Palmer, 1946; Dockery, 1977, 1980; Dockery and Siesser, 1984; Dockery and Zumwalt, 1986) and by comparison with collections from the Moodys Branch Formation at Western Washington University (collected and identified by TAH). Identification for some specimens was aided by comparison with collections made by Dr. David Dockery at the Mississippi Geological Survey. Most specimens could be identified to species, but some could only be keyed out to genus. If these specimens represented a genus that was not present among the identified species, e.g., Nucula sp., then all specimens of Nucula were counted as one species in measurements of diversity. Generic level identifications were ignored in estimates of species extinctions.

Direct comparison of the fauna from the Yazoo Formation with that of the Moodys Branch or Red Bluff Formations is complicated by the unusually deep-water paleoenvironment of the Yazoo. It is difficult to determine whether differences in the fauna between the Yazoo and surrounding units are attributable to temporal or facies differences. In order to ameliorate this bias, we surveyed the specimens from the 0.25 $\mathrm{mm}$ sieves for additional species not found in the larger-sized collection. 


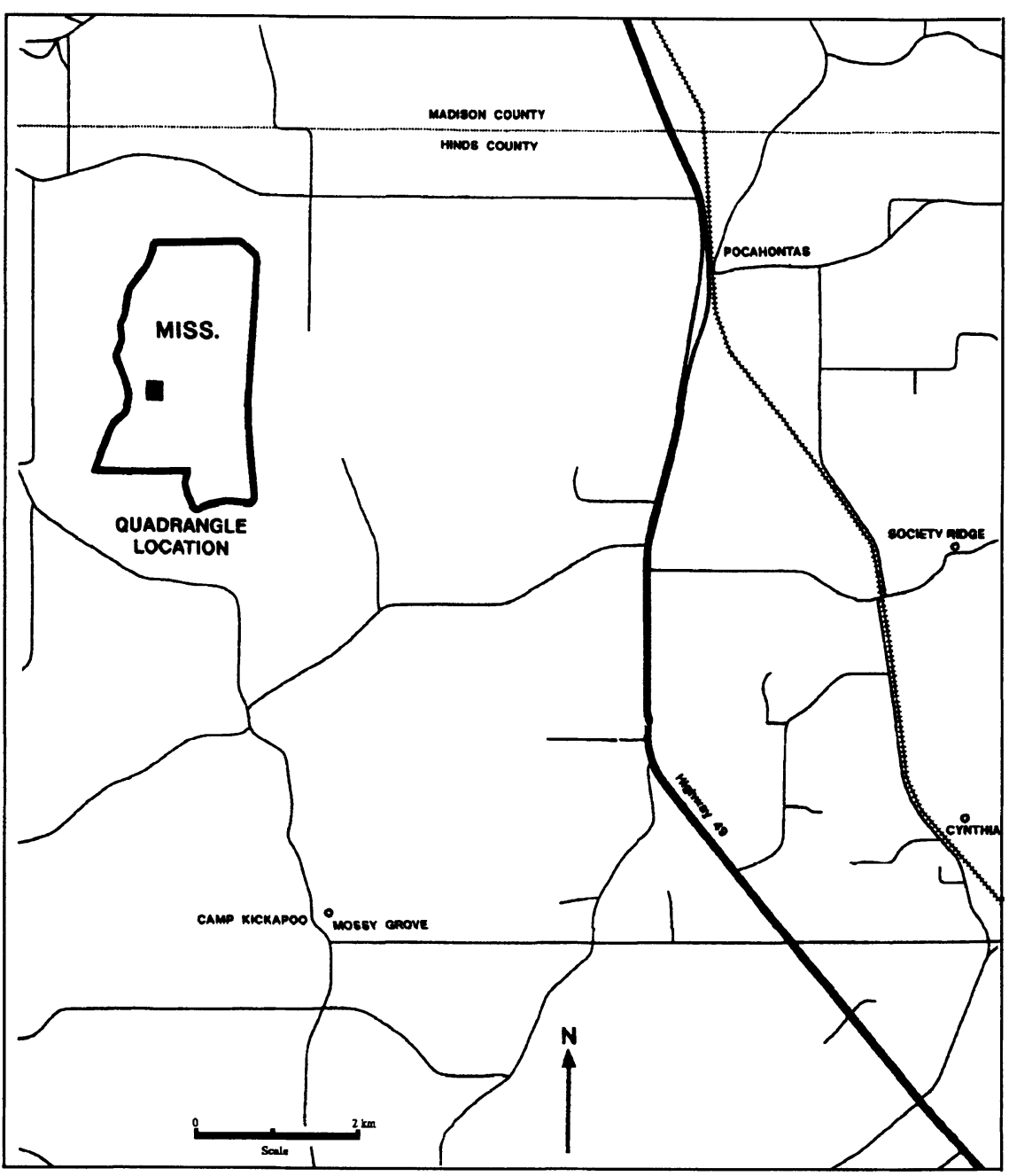

FIGURE 2-Map of Pocahontas 7.5' quadrangle with location of Cynthia Pit. Modified from Dockery et al. (1991).

Many benthic molluscs broadcast planktonic larvae that drift far from their parents. Some of these larvae may settle outside their preferred habitat and die before reaching adulthood, thus not appearing in collections of adults (Hansen, 1981, 1984). In many cases, these juvenile specimens can be identified by carefully comparing them with the larval and juvenile shells preserved on adult specimens found in other outcrops (Hansen, 1981, 1984).

The earliest Oligocene fauna was sampled from two localities on the Chickasawhay River that span the E-O boundary, MGS 35 and MGS 38 (MacNeil and Dockery, 1984; Pasley and Hazel, 1995). A total of 10 bulk

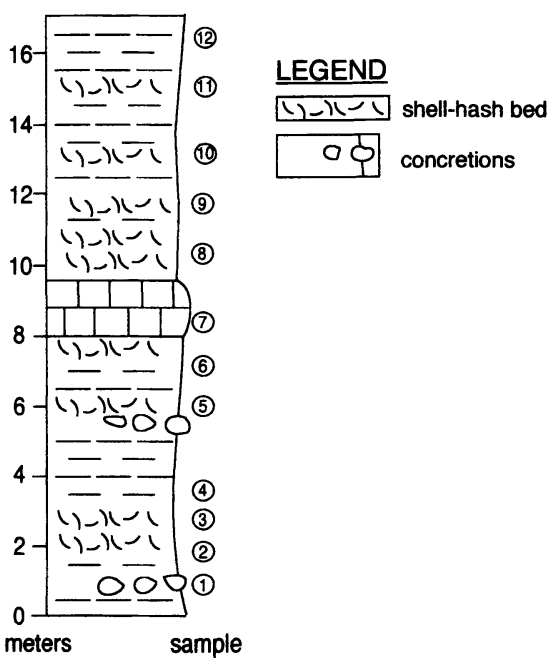

FIGURE 3-Measured section of the Cynthia Pit locality with sample levels.

found as adults. Six molluscan taxa were found only as float. The adult, juvenile and float collections produced a total of 82 molluscan taxa from Cynthia Pit (Table 1). Three solitary coral species were also identified. Of the 58 molluscan taxa identified from float collections by previous workers (Dockery and Siesser, 1984; Dockery and Zumwalt, 1986), all but five were accounted for in this study. Therefore, 29 molluscan taxa were added to published faunal lists bringing the total molluscan count for Cynthia Pit to 87 taxa (Table 1). Of these 87 taxa, 70 were identifiable to species. Of these 70 species, 52 (74\%) have been found in the Moodys Branch Formation or below. This study added 31 species to the Yazoo's gamma diversity calculated in Hansen (1987) bringing the total reported number of molluscan species for the Yazoo Formation to 117 (Fig. 4).

The Red Bluff collections yielded 85 taxa from 4298 individuals. The total number of species reported in the literature from all Red Bluff localities is 145 (Dockery, 1982; MacNeil and Dockery, 1984; Fig. 4). Eight species of molluses from Cynthia Pit were also found in the Red Bluff Formation, giving an apparent molluscan extinction of $88.6 \%$ across the E-O boundary ( 8 survivors out of 70 species). 


\section{DISCUSSION}

Despite the additional species documented in this report, there still appears to have been a substantial decline in the gamma diversity between the Moodys Branch (273 species) and Yazoo Formations (117 species; Fig. 4). However, it is difficult to compare the two formations directly because the generally poor preservation of the Yazoo Formation gives it a smaller effective outcrop area than the Moodys Branch. The preservation of the Yazoo at Cynthia Pit is excellent, but this is only one outcrop compared to dozens of outcrops of well-preserved Moodys Branch sites found throughout the Mississippi coastal plain. In addition, the Moodys Branch Formation contains fossils from many different communities along an environmental transect, whereas the Cynthia section possesses a much narrower range of communities. This disparity in the extent of fossiliferous exposure of the two formations will produce an obvious bias in the gamma diversities. The Yazoo Formation's gamma diversity will be underestimated relative to the Moodys Branch.

To arrive at a better assessment of Yazoo diversity relative to that of the Moodys Branch, the fauna of Cynthia Pit was compared to individual molluscan assemblages of the Moodys Branch. Five molluscan assemblages (A-E) have been identified from the Moodys Branch representing a depth gradient from near shore (A) to inner middle shelf (D and E; Elder and Hansen, 1981). These assemblages lived in narrowly defined facies belts and were usually restricted to one or two localities, making them much more comparable to the fauna of Cynthia Pit in their environmental breadth and sample size. This study identified two molluscan assemblages in Cynthia Pit, a lower, somewhat deeper-water assemblage dominated by gastropods (designated CPL; samples 1-6, Fig. 3 ) and an upper, slightly shallowerwater assemblage dominated by suspension-feeding bivalves (CPU; samples 7-12, Fig. 3). The taxonomic
TABLE 1-List of Molluscan taxa from Cynthia Pit.

Bivalvia

Nucula sp.

Nuculana sp.

Yoldia (Calorhadia) reginajacksonis (Harris)

Yoldia sp. A

Yoldia sp. B

Barbatia ludoviciana? Harris

Limopsis sp.

Modiolus? sp.

Trinacria? sp.

Atrina sp.

Chlamys danvillensis Weisbord in Tucker-Rowland

Ostrea falco Dall

Gonimyrtea curta (Conrad)

Venericardia (Rotundicardia) diversidentata Meyer

Venericardia (Venericor) apodensata Gardner and Bowles

Lirodiscus sp.

Nemocardium (Nemocardium) nicoletti (Conrad)

Kelliella boettgeri? Meyer

Pitar (Pitar) securiformis (Conrad)

Corbula (Caryocorbula) densata (Conrad)

Caestocorbula wailesiana Harris in Dall

Periploma sp.

Spheniopsis mississippiensis? (Meyer)

B, F, J

B, F, J

B, F, J

$\mathrm{B}, \mathrm{J}$ ?

$\mathrm{B}, \mathrm{J}$ ?

B, F

$\mathrm{B}, \mathrm{J}$

J

B

F

B, F

$\mathrm{B}, \mathrm{F}$

$\mathrm{B}, \mathrm{J}$

B

F

J

B, F, J

J

B, F, J

$\mathrm{B}, \mathrm{J}$ ?

B, F, J

B

B

Gastropoda

Ottoina? sp.

Teinostoma (Idioraphe) verrilli Meyer

Solariorbus subangulatus (Meyer)

Architectonica (Architectonica) bellistriata Conrad in Wailes

Architectonica (Granosolarium) meekana Palmer

Turritella arenicola danvillensis Stenzel and Turner

Turritella perdita jacksonensis Cooke

Turritella sp. A

Mathilda regularis (Meyer)

Bittium koeneni Meyer

Cirsotrema (Coroniscala) danvillense Palmer

Melanella jacksonensis (de Gregorio)

Niso umbilicata (I. Lea)

Calyptraea (Trochita) aperta (Solander)

Natica permunda Conrad in Wailes

Polinices weisbordi Palmer

Hexaplex (Hexaplex) supernus (Palmer)

Tritiaria albirupina (Harris)

Pseudoliva vetusta perspectiva Conrad in Gabb

Siphonalia sullivani ouachitae Palmer

Pyramimitra terebraeformis? (Conrad)

Cantharus sp.

Levifusus spiniger (Conrad)

Latirus sp.

Tritonoatractus montgomeriensis (Vaughan)

Tritonoatractus pearlensis danvillensis Palmer

Mazzalina inaurata oweni (Dall)

Athleta sp.

Caricella howei Palmer

Bonellitia jacksonica (Cooke)

Bullata semen jacksonensis (Meyer)

Conomitra hammakeri (Harris)

B
B, J
B, J
F
F
B, F, J
B, F
B, J
J
B, J
B, F
B, J
B, J
B
B, F, J
B, F, J
B, F
B, F
F
B, F
B, J
D
B, F?
B, J
D
B, F, J
D
B, F
F
B, F
B
B, F, J


TABLE 1-Continued.

\begin{tabular}{ll}
\hline \hline Coronia nodulina ouachitensis Harris & \\
Coronia conjuncta (Casey) & $\mathrm{B}$ \\
Coronia montgomeryensis (Harris) & $\mathrm{B}, \mathrm{J} ?$ \\
Sinistrella americana (Aldrich) & $\mathrm{B}$ \\
Eopleurotoma? sp. & $\mathrm{B}, \mathrm{J}$ \\
Pleurofusia danvicola Harris & $\mathrm{F}$ \\
Turricula plutonica weisbordi Harris & $\mathrm{B}, \mathrm{F}$ \\
Eucheilodon crenocarinata Heilprin & $\mathrm{B}, \mathrm{F}$ \\
Pseudotoma heilprini (Aldrich) & $\mathrm{B}, \mathrm{F}$ \\
Cochlespira bella polita Harris & $\mathrm{B}$ \\
Cordieria ludoviciana (Vaughan) & $\mathrm{B}, \mathrm{F}$ \\
Infracoronia ludoviciana normani Harris & $\mathrm{D}$ \\
Eodrillia? sp. & $\mathrm{B}, \mathrm{F}$ \\
Microdrillia ouachitae Harris & $\mathrm{J}$ \\
Asthenotoma danvitexa Harris & $\mathrm{B}$ \\
Cymatosyrinx palmerae Harris & $\mathrm{B}$ \\
Pyramidella (Syrnola) meyeri (Cossman) & $\mathrm{B}, \mathrm{F}$ \\
Pyramidella bastropensis Harris & $\mathrm{B}, \mathrm{J}$ \\
Turbonilla (Strioturbonilla) major Meyer & $\mathrm{J}$ \\
Odostomia jacksonensis & $\mathrm{J}$ \\
Acteon annectens Meyer & $\mathrm{B}, \mathrm{J}$ \\
?Tornatellaea lata (Conrad) & $\mathrm{B}$ \\
Ringicula sp. & $\mathrm{B}$ \\
Scaphander jacksonensis? Palmer & $\mathrm{B}, \mathrm{F}, \mathrm{J}$ \\
Abderospira oviformis (Meyer) & $\mathrm{B}, \mathrm{J}$ \\
Mnestia meyeri (Cossman) & $\mathrm{B}, \mathrm{J}$ \\
Retusa (Cylichnina) jacksonensis (Meyer) & $\mathrm{B}, \mathrm{J}$ \\
Bovicornu eocenense Meyer & $\mathrm{B}, \mathrm{J}$ \\
Limacina sp. & $\mathrm{J}$ \\
Scaphopoda & $\mathrm{J}$ \\
Dentalium sp. & \\
Cadulus sp. & $\mathrm{B}, \mathrm{F}, \mathrm{J}$ \\
Cephalopoda & $\mathrm{B}, \mathrm{F}, \mathrm{J}$ \\
Belosaepia sp. & \\
\hline & $\mathrm{D}$ \\
\hline
\end{tabular}

$\mathrm{B}=$ Identified in bulk collections.

$\mathrm{D}=$ Not identified in this study. Recorded in Dockery and Siesser (1984).

$\mathrm{F}=$ Identified in float collection.

$\mathrm{J}=$ Identified in juvenile collections.

composition of CPU bears some similarity to assemblage D of the Moodys Branch Formation (interpreted as being from a middle shelf environment; Elder and Hansen, 1981). Bivalves common in assemblage $D$, such as Caestocorbula, Corbula, Pitar, and Limopsis are also common constituents in CPU. CPL is rich in deep-water gastropods and shows fewer similarities with the shallowwater assemblages of the Moodys Branch.

Species richness (number of species per sample) is highly dependent upon sample size. Therefore, any

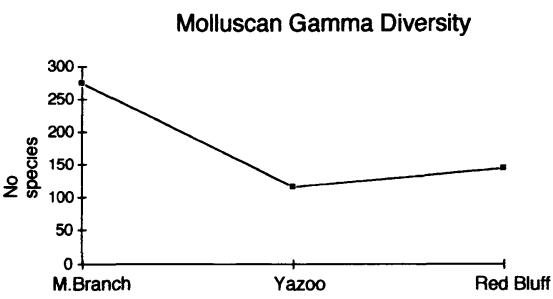

FIGURE 4-Late Eocene molluscan gamma diversity. Data compiled from this study and Hansen (1987).

comparison of samples of unequal size. Diversity is portrayed graphically as a function of the expected number of species versus sample size. The rarefaction curve of the CPU fauna lies well within the range of values exhibited by the Moodys Branch assemblages (Fig. 5). There is no significant difference in the rarefaction curves between CPU and Moodys Branch assemblages $\mathrm{C}$ and $D$ (expected species numbers for CPU and assemblages $\mathrm{C}$ and D overlap at two standard deviations).

The Shannon-Weaver index $\left(\mathrm{H}^{\prime}\right)$ is a species diversity measure that takes into account the evenness of distribution of the species abundances. As such, it tells something about the hostility of the environment in which an assemblage occurs because a stressed assemblage will tend to be dominated by a few species and produce a low $\mathrm{H}^{\prime}$ value. The $\mathrm{H}^{\prime}$ values of CPL and CPU are comparable to the highest values of the Moodys Branch assemblages (Table 2). All of these measures of alpha (within habitat) species diversity suggest the Cynthia Pit assemblages are fully as diverse as equally sized samples of the Moodys Branch and show no obvious signs of stress as might be expected if they were part of a prolonged diversity decline.

Of course, the geologic ranges of species are more germane to an assessment of extinction than species diversity. If we take the species lists of the Moodys Branch Formation and Cynthia Pit at face value, we would arrive at an extinction percentage of $81 \%$ sometime within the late Eocene (273 species in the Moodys Branch with 52 surviving into Cynthia Pit time). But to be reliable, 
TABLE 2-Species diversity values and sample sizes for molluscan assemblages of the Moodys Branch Formation and Cynthia Pit. R, (S-1/ $\operatorname{LogN}$ ); $\mathrm{H}^{\prime}$, Shannon-Weaver index; N, number of individuals; MBA-MBE, Moodys $B$ ranch assemblages A-E; CPL, Cynthia Pit lower assemblage; $\mathrm{CPU}$, Cynthia Pit upper assemblage.

\begin{tabular}{lccccccc}
\hline \hline & MBA & MBB & MBC & MBD & MBE & CPL & CPU \\
\hline $\mathrm{R}$ & 19.3 & 14.1 & 20.7 & 21.2 & 11.0 & 16.1 & 14.2 \\
$\mathrm{H}^{\prime}$ & 2.86 & 2.15 & 2.08 & 2.48 & 2.21 & 2.68 & 2.45 \\
$\mathrm{~N}$ & 2577 & 1550 & 7411 & 2808 & 1214 & 3039 & 2418 \\
\hline
\end{tabular}

extinction figures must be based on careful collection of well-preserved and well-exposed fossil deposits of the same facies both above and below the extinction event. These conditions are not applicable to the upper Eocene. The Yazoo Formation possesses only two outcrops with abundant, well-preserved fossils (Cynthia Pit and Danville Landing) restricting its effective outcrop area. Furthermore, Cynthia Pit represents a considerably deeper water environment from fossil deposits in the overlying Red Bluff Formation and the underlying Moodys Branch Formation. However, we can careful-

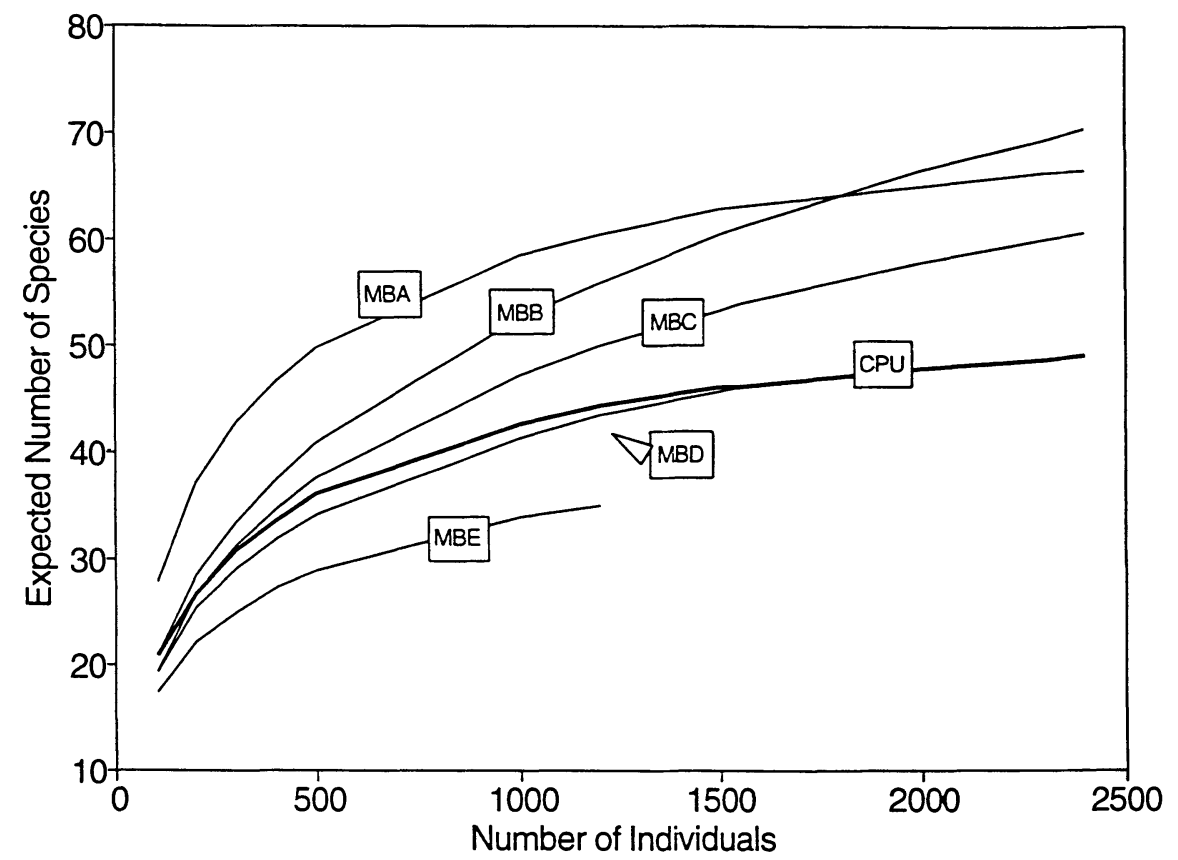

FIGURE 5-Rarefaction curves for the Moodys Branch Formation assemblages A-E (MBA$M B E)$ and the upper assemblage from Cynthia Pit (CPU). have been also found in the Moodys Branch Formation or lower horizons. The high percentage of species within the Cynthia Pit fauna that originated in the Moodys Branch combined with comparable diversity values strongly suggests that little extinction took place among molluscs between the times of deposition of the Moodys Branch and Cynthia Pit faunas. In other words, the evidence at Cynthia Pit indicates that there was probably little or no extinction of molluscs within the late Eocene, near the P15/P16 foraminiferal zone boundary.

The type Danville Landing section is the only other fossiliferous upper Eocene deposit along the Gulf Coast. Palmer and Brann $(1965,1966)$ surveyed the Danville Landing fauna and reported 49 molluscan species. Of these 49 species, 31 were identified from Cynthia Pit by this study and Dockery and Siesser (1984) and 35 have been reported from the Moodys Branch fauna as well. The relatively high diversity of and large percentage $(71 \%)$ of species present in both Moodys Branch and Danville Landing further supports the conclusion that there was a lack of major extinction within the late Eocene. The high number of Cynthia Pit species also reported from Danville Landing grants some geographic continuity to the Cynthia Pit fauna and suggests that the molluscan assemblages described in this study may be representative of the upper Yazoo. Therefore, the high diversity observed in this study is probably not an artifact based on a single, unusual locality.

The earliest Oligocene, represented in eastern Mississippi by the Red Bluff Formation, coincides with the abrupt appearance of a new molluscan assemblage of relatively high diversity dominated by suspensionfeeding bivalves. Very few Eocene species are found above the Eocene/Oligocene boundary indicating that a significant extinction had occurred prior to the earliest Red Bluff but after deposition of the Cynthia Pit sequence. The high proportion of Moodys Branch species in Cynthia Pit and their disappearance above 
the Yazoo/Red Bluff Formation(E-O) boundary suggests that the EoceneOligocene extinction event was severe and abrupt among molluses. Therefore, the overall pattern of late Eocene molluscan extinctions probably occurred in two large steps, one at the middle/late Eocene boundary where $88 \%$ of the molluscan species went extinct (Hansen, 1987) and one at or near the Eocene-Oligocene boundary where extinction probably exceeded $90 \%$. This estimate agrees with Dockery's (1984) calculation that $96.2 \%$ of Jackson species did not survive past the end of the Eocene. The sudden appearance of a relatively high diversity fauna is in contrast with the pattern observed at the Cretaceous-Tertiary boundary. Hansen et al. (1993) reported that the molluscan fauna following the latest Cretaceous extinctions was characterized by low diversity and the predominance of deposit feeders. The absence of a low diversity assemblage suggests that the molluscan fauna had recovered from the extinction by the earliest Oligocene.

\section{CONCLUSIONS}

Benthic molluscan gamma diversity suffered two major declines between the middle and end of the Eocene. The first occurred at the middle/late Eocene boundary where approximately $88 \%$ of the molluscan species went extinct. Based on comparable species composition and alpha diversities between Cynthia Pit and the Moodys Branch assemblages, this study concludes that a second extinction occurred after deposition of the Cynthia Pit sequence and prior to the deposition of the earliest Red Bluff, at or very near the end of the Eocene. Our data suggest that the final Eocene molluscan extinction was large, probably exceeding $90 \%$. This pattern is in contrast with the stepped extinctions exhibited by the foraminifera and nannoplankton.

\section{ACKNOWLEDGMENTS}

We thank David Dockery for aid in locating collecting sites and for pro- viding the Danville Landing data, Patricia Kelley for assistance in the field, and William Sliter for aid in data analysis. Dan Millikan and Jennifer Berke assisted in data processing. The manuscript benefited greatly from reviews by David Dockery and an anonymous reviewer. Support for this study was provided by a grant from Sigma Xi and National Science Foundation Grant EAR8915725.

\section{REFERENCES}

Alvarez, W., Asaro, F., Michel, H.V., and ALVAREZ, L., 1982, Iridium anomaly approximately synchronous with terminal Eocene extinctions: Science, v. 216, p. 886-888.

AUBRY, M., 1992, Late Paleogene calcareous nannoplankton evolution: a tale of climatic deterioration: in PROTHERO, D.R. and BERGGren, W.A., eds., Eocene-Oligocene Climatic and Biotic Evolution: Princeton University Press, Princeton, New Jersey, p. 272-309.

BergGReN, W.A., KeNT, D.V., OBRADOVICH, J.D., and SwISHER III, C.C., 1992, Toward a revised Paleogene geochronology: in Prothero, D.R., and BERGgren, W.A., eds., Eocene-Oligocene Climatic and Biotic Evolution: Princeton University Press, Princeton, New Jersey, p. 29 45.

BYERLY, G.R., HAZEL, J.E., and MCCABE, C., 1988, A new late Eocene microspherule layer in central Mississippi: Mississippi Geology, v. 8, p. 1-5.

Corliss, B.H., Aubry, M., Bergaren, W.A., FENNER, J.M., KeIGWIN, JR., L.D., and Keller, G., 1984, The Eocene/Oligocene boundary event in the deep sea: Science, v. 226, p. 806-810.

DoCKERY III, D.T., 1977, Mollusca of the Moodys Branch Formation, Mississippi: Mississippi Geological Survey, Bulletin $120,212 \mathrm{p}$.

DOCKERY III, D.T., 1980, The invertebrate macropaleontology of the Clarke County, Mississippi Area: Mississippi Geological Survey, Bulletin 122, $387 \mathrm{p}$.

DOCKERY III, D.T., 1982, Lower Oligocene Bivalvia of the Vicksburg Group in Mississippi: Mississippi Bureau of Geology, Bulletin 123, $261 \mathrm{p}$.

DOCKERY III, D.T., 1984, Crisis events for Paleogene molluscan faunas in the southeastern United States: Mississippi Geology, v. 5, p. 1-7.

$\rightarrow$ DoCKERY III, D.T., 1986, Punctuated succession of Paleogene mollusks in the northern Gulf coastal plain: PALAIOS, v. 1 , p. $582-589$.

DoCKERY III, D.T., and SIESSER, W.G., 1984, Age of the upper Yazoo Formation in central Mississippi: Mississippi Geology, v. 5, p. 1-10.

DOCKERY III, D.T., STOVER, C.W., WEATHERSBY, P., STOVER, JR., C.W., and INGRAM, S.L., 1991, A continuous core through the undifferentiated Yazoo clay (late Eocene, Jackson Group) of central Mississippi: Mississippi Geology, v. 12 , p. 21-27.

DOCKERY III, D.T., and ZUMwALT, G.S., 1986, Pteropods (Mollusca: Gastropoda) from the upper Yazoo Formation (Eocene) at Cynthia, Mississippi: Mississippi Geology, v. 6, p. 9-13.

ELDER, S.R., and HANSEN, T.A., 1981, Macrofossil assemblages of the Moodys Branch Formation (upper Eocene), Louisiana and Mississippi: Mississippi Geology, v. 2, p. 6-11.

GANAPATHY, R., 1982, Evidence for a major impact on the earth 34 million years ago: implication for Eocene extinctions: Science, v. 216, p. 885-886.

HANSEN, T.A., 1981, Fossil molluscan larvae: A new biostratigraphic tool: Science, v. 214, p. 915-916.

HANSEN, T.A., 1984, The biostratigraphic use of larval and juvenile mollusks: Geological Society of America Bulletin, v. 95, p. 1102-1107.

$\rightarrow$ HANSEN, T.A., 1987, Extinction of late Eocene to Oligocene molluscs: relationship to shelf area, temperature changes, and impact events: PALAIOS, v. 2, p. 69-75.

HANSEN, T.A., 1988, Early Tertiary radiation of marine molluscs and the long term effects of the Cretaceous-Tertiary extinction: Paleobiology, v. 14, p. 37-51.

HANSEN, T.A., 1992, The patterns and causes of molluscan extinction across the Eocene/Oligocene boundary: in PROTHERO, D.R., and BERGGREN, W.A., eds, EoceneOligocene Climatic and Biotic Evolution: Princeton University Press, Princeton, New Jersey, p. 341-348.

HANSEN, FARRELL, B.R., and UPSHAW III, B., 1993, The first 2 million years after the Cretaceous/Tertiary extinction: late and paleoecology of the molluscan recovery: Paleobiology, v. 19, p. 251-265.

HARRIS, G.D., and PALMER, K.V.W., 19461947, The Mollusca of the Jackson Eocene of the Mississippi embayment (Sabine River to the Alabama River): Bulletins of American Paleontology, v. 30, 563 p.

$\rightarrow$ HAZEL, J.E., 1989, Chronostratigraphy of upper Eocene microspherules: PALAIOS, v. 4, p. 318-329.

KELLER, G., 1983, Biochronology and paleoclimatic implications of middle Eocene to Oligocene foraminifera: Marine Micropaleontology, v. 7, p. 463-486.

KeLLER, G., 1986, Stepwise mass extinctions and impact events: late Eocene to early Oligocene: Marine Micropaleontology, v. 10, p. 267-293.

Keller, G., MACleod, N., and BarRera, E., 1992, Eocene-Oligocene faunal turnover 
in planktic foraminifera and Antarctic glaciation: in PROTHERO, D.R. and BERGGREN, W.A., eds., Eocene-Oligocene Climatic and Biotic Evolution: Princeton University Press, Princeton, New Jersey, p. 218-244.

MACNEIL, F.S., and DockeRY III, D.T., 1984, Lower Oligocene Gastropoda, Scaphopoda, and Cephalopoda of the Vicksburg Group in Mississippi: Mississippi Bureau of Geology, Bulletin 124, 416 p.

Miller, K.G., BergGren, W.A., ZhANG, J., and PAlMer-Julson, A.A., 1991, Biostratigraphy and isotope stratigraphy of upper Eocene microtektites at Site 612: How many impacts?: PALAIOS, v. 6, p. 17-18.

Palmer, K.V.W., and BranN, D.C., 19651966, Catalogue of the Paleocene and
Eocene Mollusca of the southern and eastern United States: Bulletins of American Paleontology, v. 48, 1057 p.

PASLEY, M.A., and HAZEL, J.E., 1995, Revised sequence stratigraphic interpretation of the Eocene-Oligocene boundary interval, Mississippi and Alabama, Gulf Coast Basin, U.S.A.: Journal of Sedimentary Research, v. B65, p. 160-169.

OBRADOVICH, J.D., DOCKERY III, D.T., and SwISHER, C.C., $1993,{ }^{40} \mathrm{Ar}-{ }^{39} \mathrm{Ar}$ ages of bentonite beds in the upper part of the Yazoo Formation (upper Eocene), westcentral Mississippi: Mississippi Geology, v. 14, p. 1-9.

SMITH, S.M., and Zumwalt, G.S., 1987, Gravity flow introduction of shallow water microfauna into deep water depositional environments: Mississippi Geology, v. 8, p. $1-8$.
SNYDER, S.W., MuEller, C., and Miller, K.G., 1984, Eocene-Oligocene boundary: biostratigraphic recognition and gradual paleoceanographic change at DSDP Site 549: Geology, v. 12, p. 112-115.

THOMAs, E., 1992, Middle Eocene-late Oligocene bathyal benthic foraminifera (Weddell Sea): faunal changes and implications for ocean circulation: in PROTHERO, D.R., and BERGGREN, W.A., eds., Eocene-Oligocene climatic and $\mathrm{Bi}$ otic Evolution: Princeton University Press, Princeton, New Jersey, p. 245271.

WEI, W., 1991, Evidence for an earliest Oligocene abrupt cooling in the surface waters of the Southern Ocean: Geology, v. 19 , p. 780-783.

\section{ACCEPTED MAY 5, 1995}

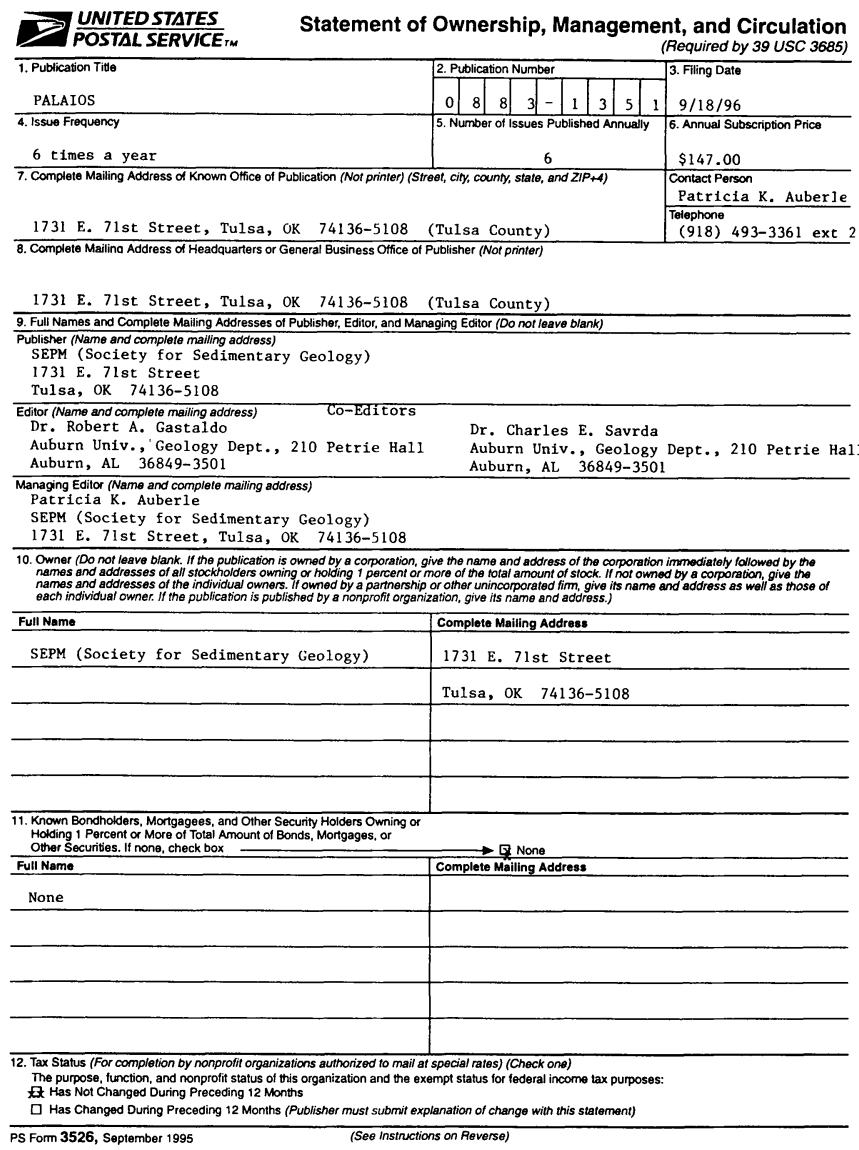

\begin{tabular}{|c|c|c|c|}
\hline \multicolumn{2}{|c|}{$\begin{array}{l}\text { 13. Pubicalion The } \\
\text { PALAIOS }\end{array}$} & \multicolumn{2}{|l|}{$\begin{array}{l}\text { 14. Issue Date for Circutabion Data Below } \\
\text { June, } 1996\end{array}$} \\
\hline & Extont and Neture of Cliculation & 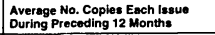 & 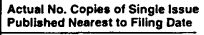 \\
\hline \multicolumn{2}{|c|}{ a. Total Number of Copies (Net press nun) } & 2,000 & 1,900 \\
\hline \multirow{2}{*}{ 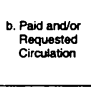 } & 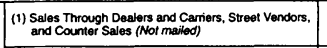 & $-0-$ & $-0-$ \\
\hline & 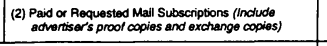 & $-0-$ & $-0-$ \\
\hline \multicolumn{2}{|c|}{ 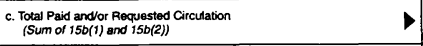 } & 1,623 & 1,559 \\
\hline \multicolumn{2}{|c|}{ 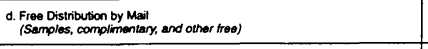 } & 14 & 14 \\
\hline \multicolumn{2}{|c|}{-. Free Distribution Ousisio the Mail (Camiers or other manns) } & $-0-$ & $-0-$ \\
\hline \multicolumn{2}{|c|}{ 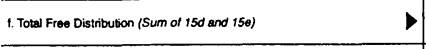 } & 14 & 14 \\
\hline \multicolumn{2}{|c|}{ 9. Total Distritustion (Sum of 15C and 15n) } & 1,637 & 1,573 \\
\hline \multirow{2}{*}{$\begin{array}{l}\text { n. Copies not } \\
\text { Distributec }\end{array}$} & (1) Otices Use, Lethovers, Spolied & 363 & 327 \\
\hline & (2) Retums trom News Agents & & \\
\hline \multicolumn{2}{|c|}{ i. Total (Sum of 15g, 15h(1), and 15h(2)) } & 2,000 & 1,900 \\
\hline \multicolumn{2}{|c|}{$\begin{array}{l}\text { Percenn Paid andolo Raguasted Circulation } \\
(15 c / 159 \times 100)\end{array}$} & 100 & 100 \\
\hline \multicolumn{4}{|c|}{ 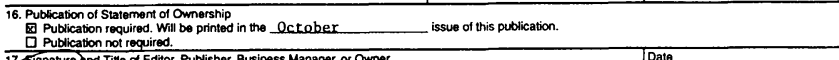 } \\
\hline \multicolumn{3}{|c|}{ 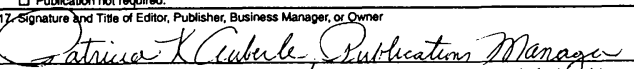 } & 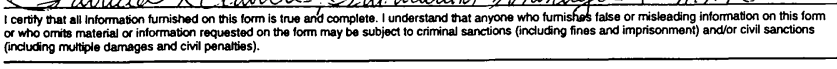 \\
\hline \multicolumn{4}{|c|}{ Instructions to Publishers } \\
\hline 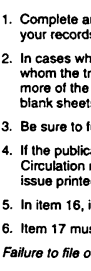 & 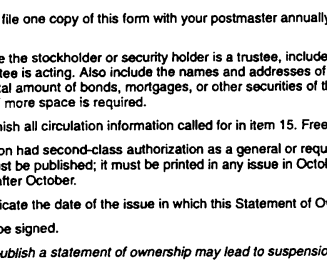 & 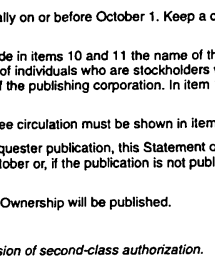 & 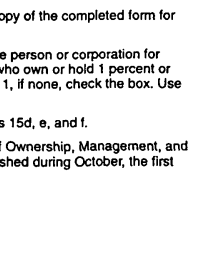 \\
\hline
\end{tabular}

